\title{
New Malaxis species (Orchidaceae, Epidendroideae) from Colombia
}

\author{
Dariusz L. Szlachetko • Marta Kolanowska
}

Received: 9 March 2013/Accepted: 8 July 2013/Published online: 27 July 2013

(C) The Author(s) 2013. This article is published with open access at Springerlink.com

\begin{abstract}
Two new species of the genus Malaxis are described and illustrated based on the Colombian material. Their taxonomic affinities are briefly discussed and the relevant floral elements of the most similar species are illustrated. The differences between genera Malaxis and Micorstylis are compared.
\end{abstract}

Keywords Biodiversity - Malaxis $\cdot$ Microstylis .

New species $\cdot$ Neotropics

\section{Introduction}

The delimitation of the genera within the cosmopolitan orchid subtribe Malaxidinae Benth. \& Hook.f. has been discussed for years. The delicate, membranous leaves together with the inconspicuous, delicate, usually tiny or small flowers, which are often poorly preserved in the herbarium material, make this group a challenging study object. The inadvertent examination of the dried plants led even to the description of the new family Pycnanthaceae (Ravenna 2011) based on the Malaxis Sol. ex Sw. specimen (Nicola 2012).

The recent comprehensive morphological outcome and molecular research (Cameron 2005; Szlachetko and Margońska 2006) clarified the relationships within Malaxidinae and resulted in description of several new genera (e.g. González-Tamayo and Szlachetko 1998; Margońska 2006; Margońska and Szlachetko 2001; Szlachetko et al. 2008).

D. L. Szlachetko · M. Kolanowska ( $\square)$

Department of Plant Taxonomy and Nature Conservation,

University of Gdańsk, ul Wita Stwosza 59,

80-308 Gdańsk, Poland

e-mail: martakolanowska@wp.pl
Most of them were separated or restituted from Malaxis s. 1., which is the largest and one of the poorest recognized taxa of the subtribe. The genus was described in the eighteenth century by Olof Swartz (1788) and until recently it included species of Microstylis Eaton. Both taxa are superficially similar and the latter was initially considered only as a section within Malaxis (Nuttall 1818). Both genera are clearly separated according to their androecium's and gynoecium's structures (Szlachetko and Margońska 2006)-differences in the gynostemium characters are compiled in Table 1. From all other South American Malaxidinae the representatives of Malaxis are separable by the non-resupinate flowers, with the lip basally flat, which does not clasp the gynostemium base. The gynostemium is short, massive with erect anther firmly joined with the column part. Flowers of Crossoglossa Dressler \& Dodson and Liparis L.C.Rich. are variously resupinate, usually with lip situated lowermost. In both genera the base of gynostemium is clasped by the lip. The gynostemium structure also evidently distinguishes Crossoglossa and Liparis from Malaxis. In Liparis the column part is elongate, slender, arcuate and basally extended; the anther is motile, more or less incumbent with much elongate connective forming a beak-like projection. The column part of Crossoglossa is short, massive and erect with thin-walled anther being incumbent and motile as well.

The genus Malaxis predominantly includes terrestrial species, characterized by the presence of the hairy roots, fleshy, cylindrical to pseudobulbous stem and the apical racemose, unbranched inflorescence. While the dorsal sepal and petals are always free, the lateral sepals may be occasionally fused and the erect lip may be entire or lobed. According to the most recent approach (Szlachetko and Margońska 2006), the geographical range of the genus is limited to the Americas. 
Among the Neotropical countries, the Republic of Colombia is considered to be one of the most biodiverse ones. The extraordinary vascular plants flora of Colombia comprises over 24,000 species, among which Orchidaceae is the best represented family (Jørgensen et al. 2011). In 2007, Ortiz and Uribe presented the national list of orchids

Table 1 The comparative morphology of Malaxis Sol. ex Sw. and Microstylis (Nutt.) Eaton

\begin{tabular}{|c|c|c|}
\hline Character & Malaxis & Microstylis \\
\hline Inflorescence & Often subumbellate & Elongate, cylindrical \\
\hline Gynostemium & Very short, massive, erect & Short to elongate, slender, erect \\
\hline $\begin{array}{l}\text { Column } \\
\text { part }\end{array}$ & Vestigial, occasionally longer & Nearly as long or longer than the anther \\
\hline Anther & $\begin{array}{l}\text { Firmly joined with the gynostemium; transversely ellipsoid; } \\
\text { chambers connate basally, opening apically }\end{array}$ & $\begin{array}{l}\text { Hardly motile; dorsiventrally flattened, subquadrate to elliptic- } \\
\text { ovate; chambers parallel, opening ventrally }\end{array}$ \\
\hline Filament & Incorporated into the column part & Incorporated into the column part and clinandrium \\
\hline Stigma & $\begin{array}{l}\text { Transversely elliptic to oblong, flat or slightly concave at the } \\
\text { base }\end{array}$ & Oblong to elliptic, basally deeply concave \\
\hline Rostellum & $\begin{array}{l}\text { Obscurely 3-lobed, usually with the lateral lobes being longer } \\
\text { than the middle one }\end{array}$ & $\begin{array}{l}\text { Triangular to ligulate, with the middle lobe being longer than } \\
\text { both laterals }\end{array}$ \\
\hline Viscidium & 2, small, delicate, membranous & Single, minute, semifluid \\
\hline
\end{tabular}

Fig. 1 Malaxis calos-parrae Szlach. \& Kolan. a Dorsal sepal, b petal, c lateral sepal, d lip. Scale bar $2 \mathrm{~mm}$ [holotype; drawn by P. Baranow]
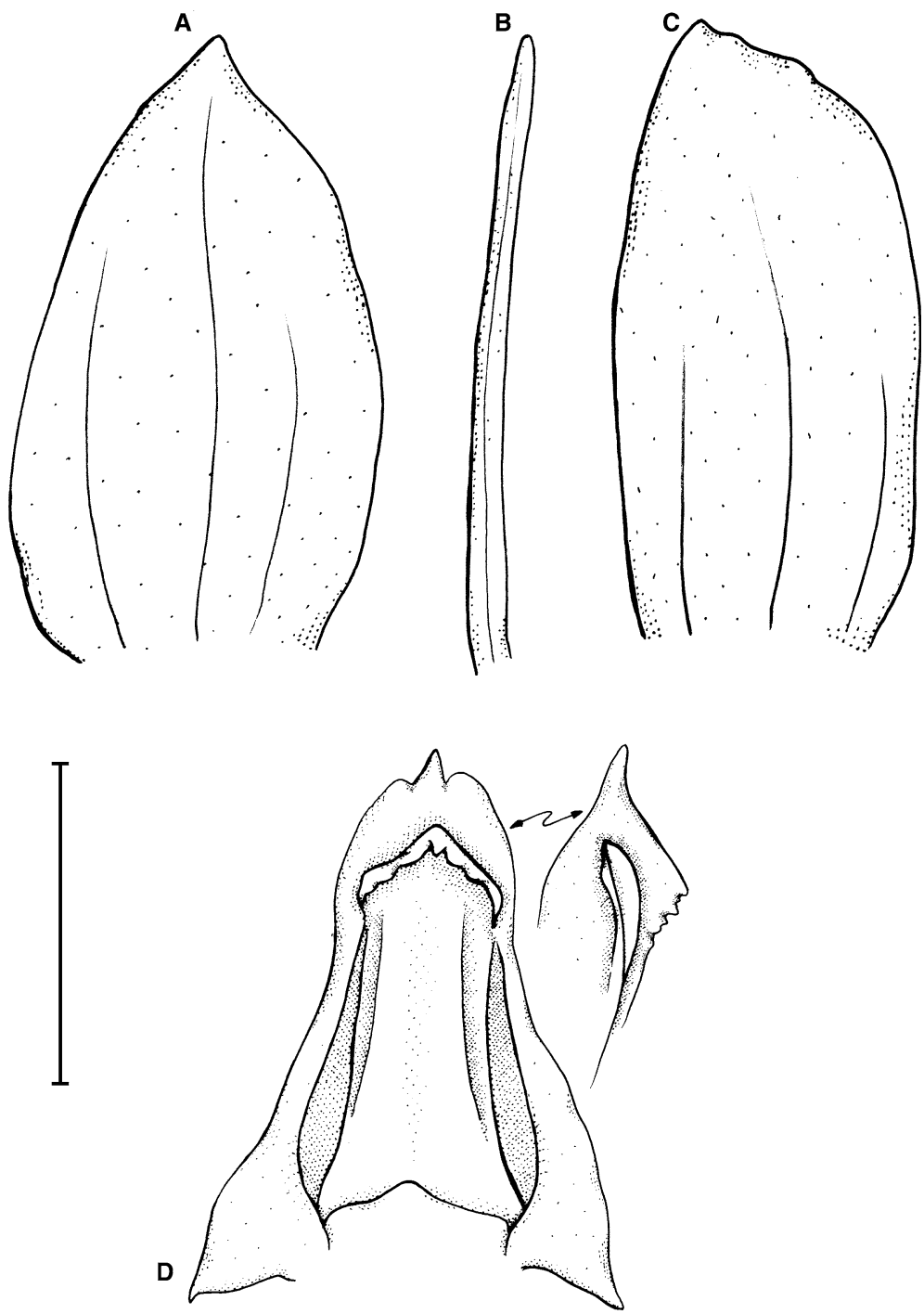


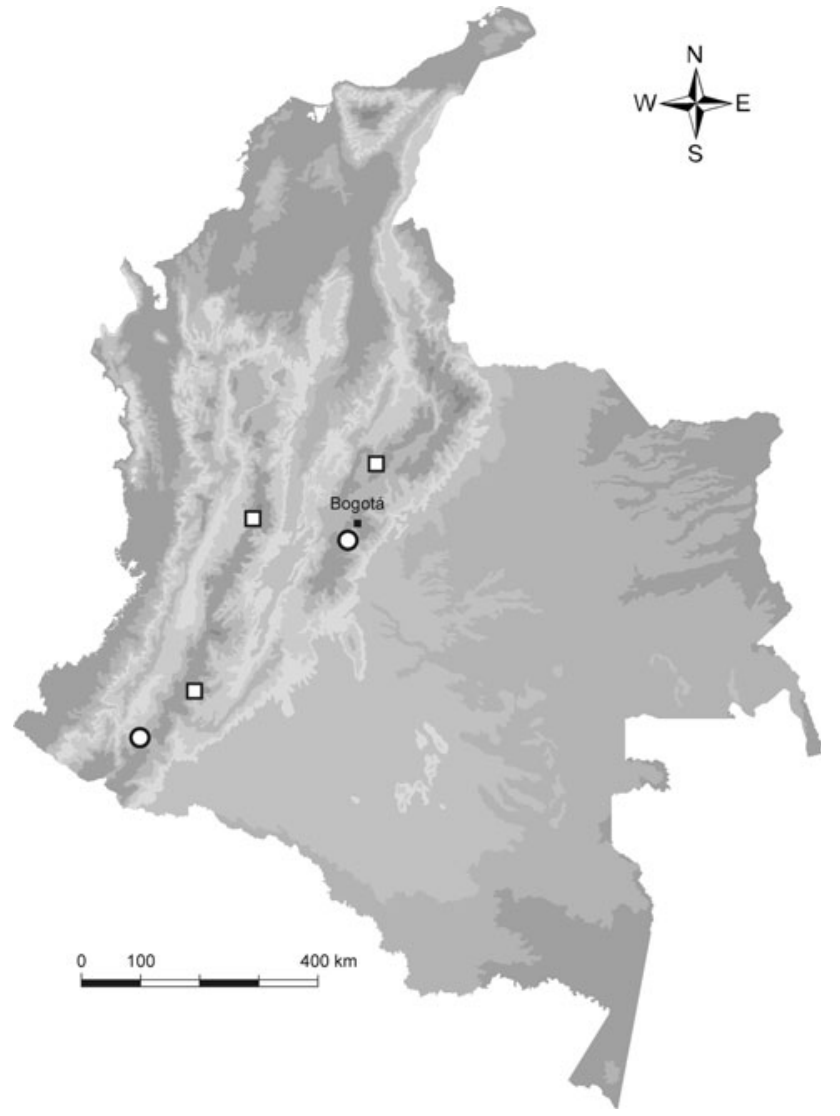

Fig. 2 Distribution of Malaxis calos-parrae (circle) and $M$. risaraldana (square)

Fig. 3 Comparison of the floral elements of Malaxis calos-parrae (a) and $M$. carpintarae (b) [drawn by $\mathrm{P}$. Baranow]
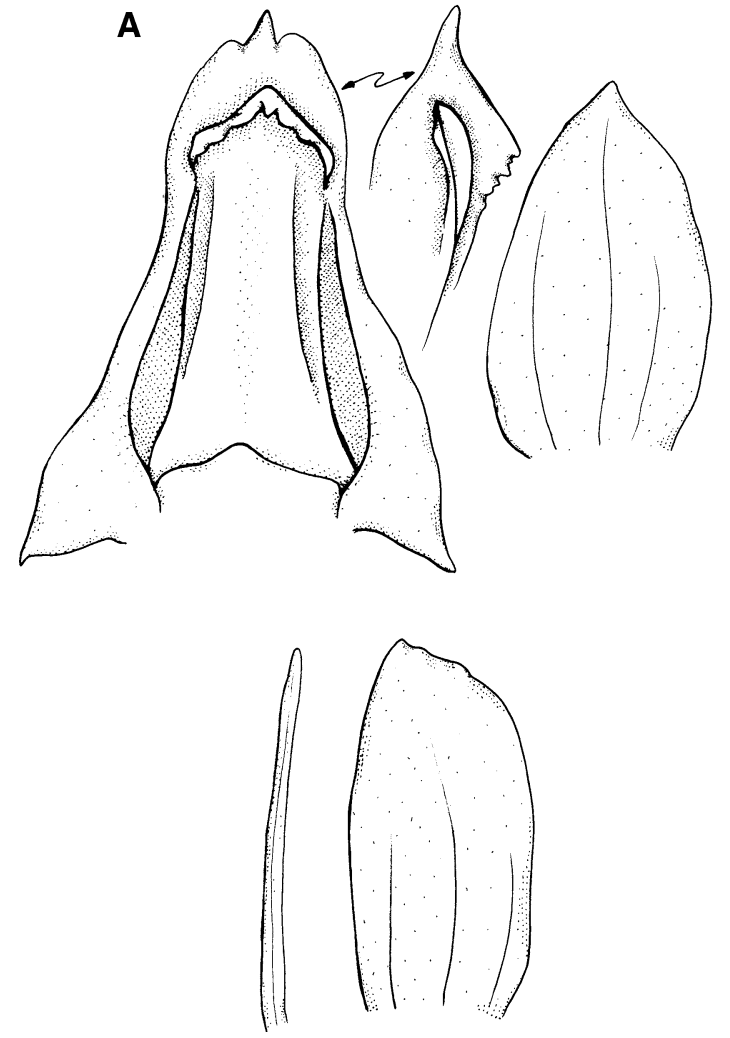

that included over 3,200 species, while just 4 years later this number exceeded 3,500 (Jørgensen et al. 2011). So far 12 of about 100 known Malaxis species were reported from Colombia. The national representatives were usually found above the altitude of $2,000 \mathrm{~m}$ growing in the marches, grasslands and forested areas (Ortiz and Uribe 2007).

The recent studies on the Colombian orchids revealed the existence of numerous new taxa occurring in this country (Kolanowska and Szlachetko 2013a, b, c; MytnikEjsmont et al. 2012; Pérez-Escobar et al. 2013a, b; Szlachetko and Kolanowska 2013a, b, c; Szlachetko et al. 2013). During the examination of the herbarium material of Colombian Malaxidinae we came across two distinctive Malaxis species, which are here described as new.

\section{Malaxis carlos-parrae Szlach. \& Kolan., sp. nov. (Fig. 1)}

This species appears to be related to Malaxis carpintarae Schltr., from which it differs by having acute, triangular apical lip lobe, narrowly oblong lip cavities running in twothird of the lip length, shortly apiculate basal auricles and by obliquely elliptic lateral sepals with somewhat erose apical margin.

Type: R. Guarin M. 54-Colombia, Nariño, Mpio. Chachagüí. Carretera Chachagüí a Sánchez, alt. 1,960 m (1 Dec 1965), (COL! holotype). 


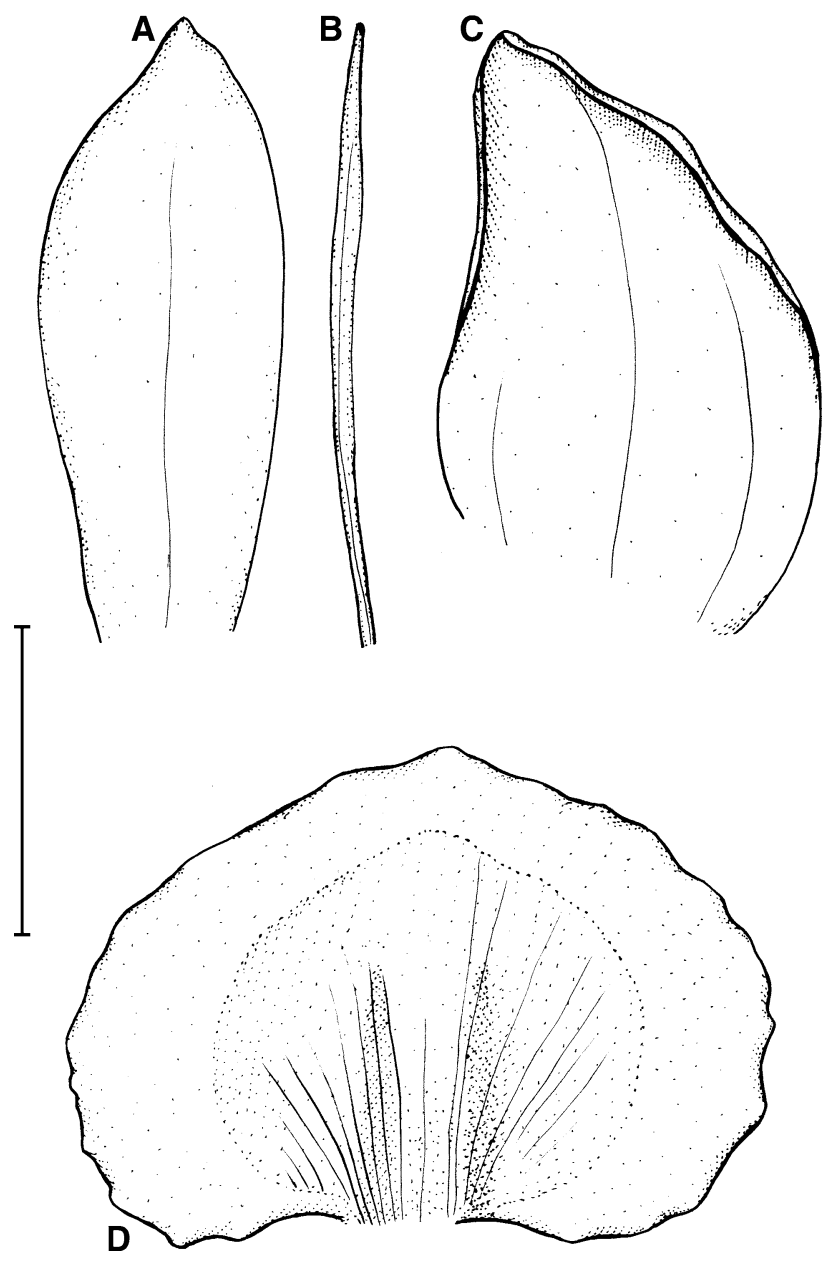

Fig. 4 Malaxis risaraldana Szlach. \& Kolan. a Dorsal sepal, b petal, c lateral sepal, d lip. Scale bar $2 \mathrm{~mm}$ [holotype; drawn by P. Baranow]

Plant ca $20 \mathrm{~cm}$ tall. Pseudobulbs to $6 \mathrm{~cm}$ long and $1.5 \mathrm{~cm}$ in diameter, bifoliate, covered with the scarious sheaths. Leaves subsessile; blade to $10 \mathrm{~cm}$ long and $4.8 \mathrm{~cm}$ wide, ovate, acute, membranaceous. Inflorescence ca $10 \mathrm{~cm}$ long, terminated by short, dense, many-flowered, subumbellate raceme ca $0.5 \mathrm{~cm}$ long. Flowers small, nonresupinate. Floral bract $1.5 \mathrm{~mm}$ long, triangular-ovate, acute. Pedicel and ovary 10-12 mm long. Dorsal sepal $4 \mathrm{~mm}$ long, $2.2 \mathrm{~mm}$ wide, elliptic-ovate, acute, obscurely 3-nerved. Petals $4 \mathrm{~mm}$ long, 0.3-0.4 mm wide, linear, obtuse, 1-nerved. Lateral sepals 3-4 mm long, 1.8-2 mm wide, obliquely elliptic, obtuse, free to the base, apical margin somewhat erose, obscurely 3-nerved. Lip $3.5 \mathrm{~mm}$ long, $2.8 \mathrm{~mm}$ wide, oblong-triangular, apex obscurely 3-lobed, with the middle lobe being the longest, triangular and acute; both lateral lobes weakly developed, rounded at the apex; lip cavities more or less two-third of the whole lip length, very narrow, separated by wide and massive ridge, terminated by a kind of prominent roof with erose margins; basal lip auricles triangular, widely spread and shortly apiculate. Gynostemium $1 \mathrm{~mm}$ long, broadly connate with the lip base.

Etymology: Dedicated to Dr. Carlos Parra Osorio, the Curator of the Nacional Herbarium in Bogotá, Colombia.

Habitat and ecology: The new species grows in the forest between 1,960 and 2,680 $\mathrm{m}$ a.s.l. It is flowering in November and December.

Distribution: The populations of this species were so far found at two Colombian localities. First one is located in the northern part of the Central Andes, just before the diverging of the mountains into Cordilleras (department of Nariño) and the other on the slopes of the Eastern Cordillera (department of Cundinamarca).

Representative specimens: R. Jaramillo M. 2336-Colombia, Cundinamarca, Entre Sibaté y La Aguadita. Bosques abajo de San Miguel, alt. 2,680 m (16 Nov 1961), (COL!); R. Guarin M. 54-Nariño, Mpio. Chachagüí, Carretera Chachagüí a Sánchez, alt. 1,960 m (1 Dec 1965), (COL!) (Fig. 2).

Taxonomic notes: The new entity appears to be related to Malaxis carpintarae Schltr., with which it shares similar habit. Both species are easily separable by flowers morphology, especially lip details and shape of lateral sepals. Apical part of the lip of M. carlos-parrae is obscurely 3-lobed, with the middle lobe being the longest, triangular and acute. Both lateral lobes are weakly developed and are rounded at the apex. Along major part of the lip two cavities can be observed. They are more or less two-third of the whole lip length and very narrow, and terminated by a kind of prominent roof with erose margin. Basal lip auricles are triangular, widely spread and shortly apiculate. In addition, all sepals are obscurely 3-nerved and lateral sepals are obliquely elliptic with somewhat erose apical margin. Apical part of the lip of Schlechter's M. carpintarae is 3-lobed, the middle lobe is the longest and ligulate. All lobes are rounded at the apex. Lip cavities are relatively broad and reaching about half of the lip length. Lip auricles are pendent and blunt. Sepals are 1-nerved, and lateral sepals are obliquely ovate-lanceolate (Fig. 3).

\section{Malaxis risaraldana Szlach. \& Kolan., sp. nov. (Fig. 4)}

Species similar to Malaxis histionantha Link, Klotzsch \& Otto, from which it is easily separable by obliquely triangular-ovate lateral sepals almost free to the base and lip form, which is reniform in outline, much wider than long, with undulate margins.

Type: Wolf \& de Wilde 2110-Colombia, Risaralda, Mpio. Santa Rosa de Cabal, ca $150 \mathrm{~m}$ SE of Termales, at the edge of forest. Flowers bronze-green, tepals translucent white to very light yellow, with few purple stripes, alt. 2,100 m (21 Nov 1985), (COL! holotype). 
Fig. 5 Comparison of the floral elements of Malaxis risaraldana (a) and $M$. histionantha (b) [drawn by P. Baranow]
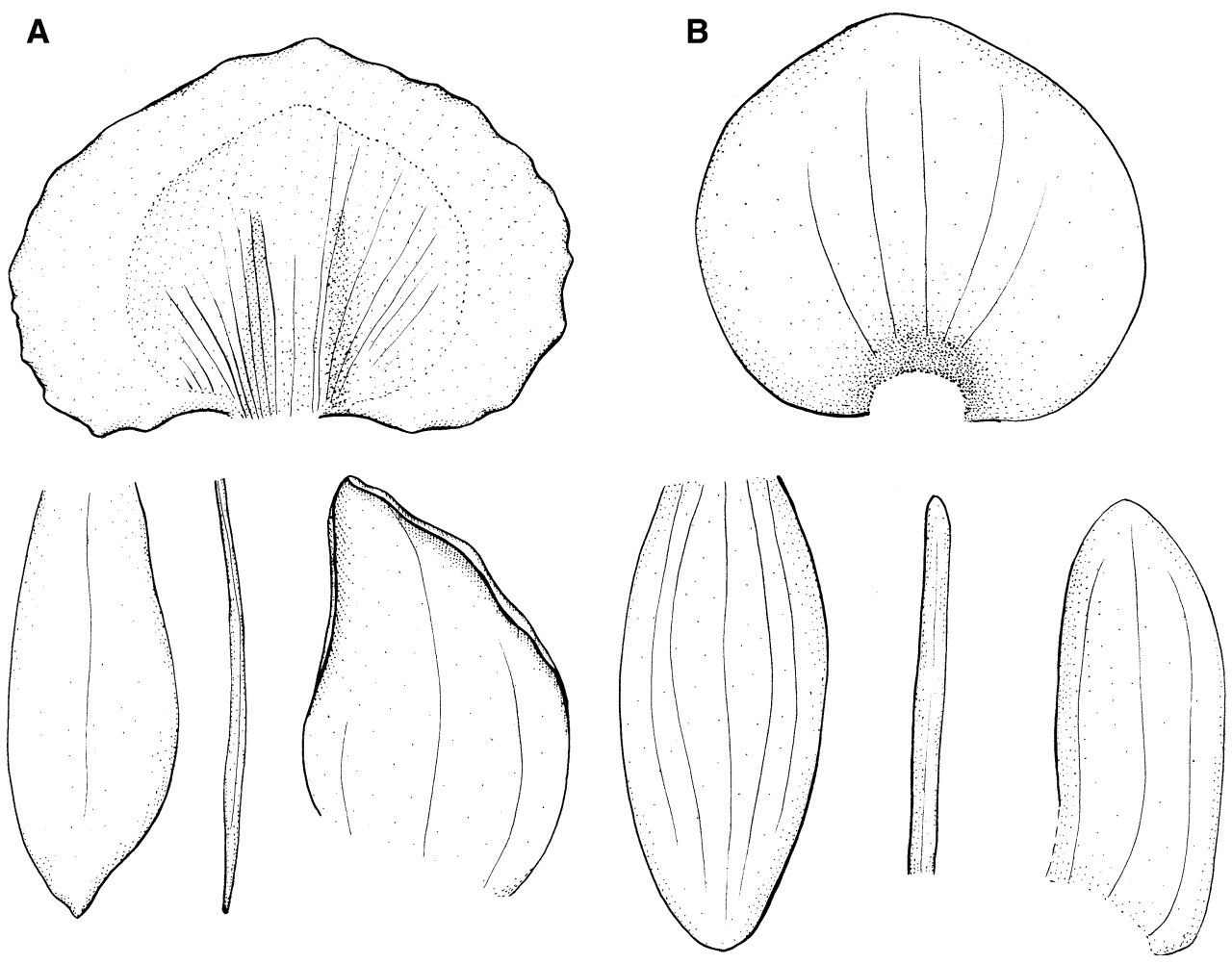

Plant ca $20 \mathrm{~cm}$ tall. Pseudobulbs to $6 \mathrm{~cm}$ long and $1.5 \mathrm{~cm}$ wide, elongate, bifoliate, covered with the scarious sheaths. Leaves subsessile; blade up to $12 \mathrm{~cm}$ long and $7.5 \mathrm{~cm}$ wide, ovate, acute, membranaceous. Inflorescence $13 \mathrm{~cm}$ long, terminated by a short (ca $0.5 \mathrm{~cm}$ long), dense, many-flowered, subumbellate raceme. Flowers small, nonresupinate, brownish-green, tepals translucent white to very light yellow, with few purple stripes. Floral bract $1.2 \mathrm{~mm}$ long, triangular-ovate, acute. Pedicel and ovary $10 \mathrm{~mm}$ long. Dorsal sepal $4 \mathrm{~mm}$ long, $1.3 \mathrm{~mm}$ wide, ligulate, with triangular and subacute apex, 1-nerved. Petals $4 \mathrm{~mm}$ long, $0.2 \mathrm{~mm}$ wide, filiform, acute. Lateral sepals $3.8 \mathrm{~mm}$ long, $2.5 \mathrm{~mm}$ wide, obliquely triangular-ovate, subobtuse at apex, almost free to the base, very obscurely 3-nerved. Lip $3.5 \mathrm{~mm}$ long, $4.7 \mathrm{~mm}$ wide, reniform in outline, much wider than long, with two shallow cavities on both sides of low central ridge, margins entire, undulate. Gynostemium $0.6 \mathrm{~mm}$ long.

Etymology: In reference to the name of Colombian department of Risaralda, where the type specimen was collected.

Habitat: The new species was found growing in a smooth bark inside the low forest with a thick leaf mulch on the ground as well as in the edge of the montane forest. The altitudinal range of this species extends from 1,600 to about 2,100 $\mathrm{m}$ a.s.l. It is flowering throughout the year.

Distribution: This species was found so far exclusively in the Colombian Central Cordillera.
Representative specimens: Schneider 337-Colombia, Boyacá, Pauna, alt. 1,600 m (8 Feb 1946), (COL!); Kapuler \& Hascall 142-Huila, Outside San Agustin in a smooth bark small treed forest with thick leaf mulch on ground and a few epiphytes (Aug 1964), (COL!); M.T. Murillo 711-Huila, San Agustin, bosque al NW del parque arqueologico (30 Aug-6 Sep 1962), (COL!); Wolf \& de Wilde 2110-Risaralda, Mpio. Santa Rosa de Cabal. ca $150 \mathrm{~m}$ SE of Termales, at the edge of forest. Flowers bronze-green, tepals translucent white to very light yellow, with few purple stripes, alt. 2,100 m (21 Nov 1985), (COL!) (Fig. 2).

Taxonomic notes: $M$. risaraldana is similar in habit to M. histionantha Link, Klotzsch \& Otto, however, both species are easily distinguishable by the shape of lateral sepals and lip. Lateral sepals of M. risaraldana are obliquely triangular-ovate, acute, obscurely 3-nerved and almost free to the base. The lip is reniform in outline, much wider than long with undulate margins. Lateral sepals of $M$. histionantha are obliquely oblong or elliptic-ovate, subobtuse and connate in the lower half. The lip of this species is almost orbicular or transversely elliptic, slightly wider than long with entire margins (Fig. 5).

Acknowledgments The curator and staff of the National Colombian Herbarium are thanked for their kind hospitality and assistance during visits and for making specimens available to study. We are grateful to Przemysław Baranow for preparing the illustration. The research described here has been supported by the Polish Ministry of Science and Higher Education (Research Grant No. 8124/B/PO1/2011/40). 
Open Access This article is distributed under the terms of the Creative Commons Attribution License which permits any use, distribution, and reproduction in any medium, provided the original author(s) and the source are credited.

\section{References}

Cameron K (2005) Leave it to the leaves: a molecular phylogenetic study of Malaxideae (Epidendroideae, Orchidaceae). Am J Bot 92:1025-1032

González-Tamayo R, Szlachetko DL (1998) A new definition of the genus Tamayorkis Szlach. (Orchidaceae, Malaxidae). Ann Bot Fenn 35:21-27

Jørgensen PM, Ulloa Ulloa C, León B, León-Yánez S, Beck SG, Nee M, Zarucchi JL, Celis M, Bernal R, Gradstein R (2011) Regional patterns of vascular plant diversity and endemism. In: Herzog SK, Martínez R, Jørgensen PM, Tiess H (eds) Climate change and biodiversity in the Tropical Andes. Inter-American Institute for Global Change Research (IAI) and Scientific Committee on Problems of the Environment (SCOPE), Sao Jose dos Campos and Paris, pp 192-203

Kolanowska M, Szlachetko DL (2013a) A new species of Hapalorchis (Spiranthinae, Orchidaceae) from Colombia. Plant Biosyst. doi:10.1080/11263504.2013.768559

Kolanowska M, Szlachetko DL (2013b) Pterichis moralesii (Cranichidinae, Orchidaceae), a new species from Colombia. Ann Bot Fennici 50:111-114

Kolanowska M, Szlachetko DL (2013c) Fernandezia ortiziana (Orchidaceae), a new species from Colombia. Ann Bot Fennici 50:68-70

Margońska HB (2006) Seidenforchis-a new genus of subtribe Malaxidinae (Orchidaceae), from Thailand. Acta Soc Bot Pol 75(4):301-307

Margońska HB, Szlachetko DL (2001) Saurolophorkis Marg. \& Szlach., gen. nov. (Orchidaceae, Malaxidinae), a new orchid genus from New Guinea. Pol Bot J 46(1):7-9

Mytnik-Ejsmont J, Szlachetko DL, Nowak S (2012) Three new species of Myrosmodes (Orchidaceae, Spiranthoideae) from
Colombia and Ecuador. Plant Syst Evol. doi:0.1007/s00606012-0690-9

Nicola VM (2012) On the identity of the new family Pycnanthaceae Ravenna. Gayana Bot 69(2):360-364

Nuttall T (1818) The genera of North American plants and catalogue of the species to the year 1817. Heartt, Philadelphia

Ortiz VP, Uribe VC (2007) Galería de Orquídeas de Colombia (CD edition). Asociación Bogotana de Orquideología, Bogotá

Pérez-Escobar O, Kolanowska M, Parra-Sánchez E (2013a) Lepanthes elizabethae (Pleurothallidinae, Orchidaceae), a new species from Colombia. Phytotaxa 79(2):58-62

Pérez-Escobar O, Kolanowska M, Rincón-Useche C (2013b) A new species of Lepanthes (Pleurothallidinae, Orchidaceae) from Colombia. Syst Bot 28(2):316-319

Ravenna P (2011) Pycnantha, a new genus of a new family of Monocotyledones, including a new species from Argentina. Onira 12:29-32

Swartz O (1788) Nova genera species plantarum seu prodromus descriptionum vegetabilium maximam partem incognitorum quae sub itinere Indiam occidentalem annis 1783-1787. Acad. M. Swederi, Stockholm

Szlachetko DL, Kolanowska M (2013a) A new species of Rhetinantha (Orchidaceae, Maxillarieae) from Antioquia, Colombia. Plant Syst Evol. doi:10.1007/s00606-013-0843-5

Szlachetko DL, Kolanowska M (2013b) A Three new species of Ponthieva (Orchidaceae, Spiranthoideae) from Colombia and Venezuela. Plant Syst Evol. doi:10.1007/s00606-013-0824-8

Szlachetko DL, Kolanowska M (2013c) New species of the genus Cranichis (Orchidaceae, Cranichidinae) from Colombia. Plant Syst Evol 299(5):979-983

Szlachetko DL, Margońska HB (2006) Redefinition of the genera Malaxis Sol. ex Sw. and Microstylis (Nutt.) Eaton (Orchidaceae, Epidendroideae). Acta Soc Bot Pol 75(3):229-231

Szlachetko DL, Margońska HB, Kułak M (2008) Nomenclatoral changes in Liparis-complex (Malaxidinae, Epidendroideae). Acta Soc Bot Pol 77(1):35-40

Szlachetko DL, Mytnik-Ejsmont J, Baranow P (2013) New species of the genus Epistephium (Orchidaceae, Vanilloideae). Plant Syst Evol. doi:10.1007/s00606-013-0815-9 